\title{
The written monuments of the ancient turks and the tuvinian poetry
}

\begin{abstract}
The Author examines the poetic features of ancient Turkic texts, comparing them with modern Tuvan poetry. Three-line inscription of the ancient Turks are studied as one of possible origins of Tuvan poetic genre "ozhuk dazhy" ("stones of the hearth"), which confirms the continuity of traditions ancient and modern literature.
\end{abstract}

Keywords: the monuments of ancient Turkic, Orkhon-Yenisey script, Tuvinian poetry, epitaph lyrics, tercet, poetic triad, three line form "ozhuk dazhy", continuity
Volume 2 Issue 6 - 2018

\author{
Lyudmila Mizhit \\ Tuvan Institute of Humanitarian and Applied Socio-economic \\ Research 4 Kochetov Str, Republic of Tuva, Russia
}

\author{
Correspondence: Lyudmila Mizhit, Tuvan Institute of \\ Humanitarian and Applied Socio-economic Research 4 \\ Kochetov Str, Republic of Tuva, Russia, Email Imizhit@mail.ru
}

\section{Introduction}

The descendants of the ancient Turkic ethnic groups of Central Asia - the Tuvinians are a nation with a long history, a kind of spiritual and material culture. Being the homeland of the Turkic peoples, Tuva saves the burial mounds of Scythians (called «Arzhaan-1», «Arzhaan-2») and Huns, stone sculptures and steles with the inscriptions «bengü taş» («eternal stone») of the ancient Turks, Uighurs and Kyrgyzs from the ancient times to our days on its territory - the ancient land that is rightfully considered the cradle of many peoples of Eurasia. And accordingly, the Tuvan literature and art culture are closely linked with the written heritage of the ancient Turks. Old Turkic inscriptions on the stone steles should be considered not only in the system of culture, language, religion and the traditional philosophy of the peoples of Central Asia, but a phenomenon of ancient literature. Monuments with inscriptions, first found about 290 years ago (the First stele with mysterious symbols was fixed in $1721 \mathrm{D}$. Messerschmidt in the valley of the river Uybat.) during long time for scientists difficult task of them could not read to the end of the 19th century. Decoding tirelessly worked prominent specialist in Turkic Philology, academician V.V. Radloff. He has correctly identified a third of the characters of the alphabet by the time when the Danish linguist W. Thomsen in 1893 he unraveled the mystery of these letters. He was able to decipher keywords türük (Turk), tenri (Tengri), kül tigin (Kul-Tegin). It turned out that they wrote the ancient Turks, had their own statehood and writing. It was a great discovery, lifted the veil on the mystery of the ages, and forced change of established history of ancient times, the history of ancient Eurasian Empire in the 6th-8th centuries ad.

Currently there are more than 140 monuments of ancient inscriptions, about 90 of them are on the territory of Tuva. ${ }^{1}$ In this connection, the Republic of Tyva regularly since 1993 (the year of the 100 anniversary of deciphering) organizes the scientific conference devoted to ancient Turkic runes that come specialists from all over the world. Orkhon monuments of written language, certain I. Stebleva as historical-heroic poem «Small inscription in honor of Kul-Tegin», «Big inscription in honor of Kul-Tegin», «The Inscription in honor of Tonyukuk» (all dated to the VIII century) is located on the banks of the Orkhon river in Mongolia. Ancient Turkic monuments, found along the Upper and Middle reaches of the Yenisei river on the territory of Tuva, Khakasia and Minusinsk basin are mostly samples epitaph lyrics of ancient Turks, related to the historical periods: the ancient Turkic (552-744's.), Uighur (745-840's.), ancient Kyrgyzs (IX-XII centuries). ${ }^{1}$ Currently there are more than 140 monuments of ancient inscriptions, about 90 of them are on the territory of Tuva. ${ }^{1}$ In this connection, the Republic of Tyva regularly since 1993 (the year of the 100 anniversary of deciphering) organizes the scientific conference devoted to ancient Turkic renice that come specialists from all over the world. Runic inscriptions of the ancient Turks, being one of the fundamental layers of Turkic literature, have artistic merit - epic principle, complex space-time continuum, the characteristic style and the internal organization of the text, etc. - and it is, as the R. Baimov, "proves the high level of artistic thinking of the ancient Turks".

The influence of ancient Turkic written monuments, as literary texts, in modern literature obviously. However, it is difficult to assert that the Orkhon-Yenisey monuments have a direct impact on the modern literature due to the fact that the ancient Turkic written language was lost, having existed for several centuries, and the evolution of written cultural tradition was interrupted. Today we can speak about historical-genetic influence never interrupted through oral tradition, historical and linguistic memory of Turkic peoples, so that, for example, in the works of Tuvan literature preserved images and motifs of ancient Turkic literature. Concepts such as "Kok denger" (Blue Sky), "Denger-Ada" (Sky-Father), "Cher-Iye" (Mother-Earth), hun (sun), ay (moon) and others are not only rich in genre system folklore, shamanistic algysh (song), but in modern poetry and prose. However, it is worth noting that were forgotten such stylistic motives epitaphs lyrics ancient Turkic as "(a)d(i)r(i)lt(i)m" (I'm separated) and "bökm(e)d(i)m" (I didn't enjoy), etc.

Thanks to decipher, translation and publication of the OrkhonYenisei monuments writing modern Tuvan writers felt poetic and aesthetic affinity with the artistic legacy of their ancestors and began to borrow and revive the genre and stylistic features epitaph lyrics, aesthetics and rhythm of ancient works. For example, the artistic experience of ancestors put it in the 1990s in the genre of crying spells "Halak" in the poetry of A. Darzhay, epitaph lyrics of Y. Kyunzegesh, A. Uerzhaa, in praise of the legendary heroic ancestors- "KokEl" (name of the area), "Bagyrnyt hylyzhy" - " Sword Bagyra" Y. Kyunzegesh, "Kezerning baldyzy" - "Keser Mace" E. Mizhit, etc. In the study of the origins of Tuvan literature and culture of a certain interest especially literary monuments of the Orkhon-Yenisey.

Literary analysis of monuments of ancient Turkic literature (from the middle of the $20^{\text {th }}$ century) in the works famous scholars V.M. Zhirmunsky, A.N. Bernshtam, A.M. Scherbak, who believe that the ancient Turkic monuments are the prosaic works, and Yenisey inscriptions described as "primitive and simple texts». ${ }^{3}$ I.V. Stebleva, 
which considers the Orkhon-Yenisei inscriptions as poetic texts constructed within the poetic canon; Bombachi A., A. von Gaben, which include inscriptions of the ancient Turks to literature in general, ${ }^{4-7}$ and others. Thus, the above scholars, no doubt, find ancient Turkic runic inscriptions monuments literature. The only question is, whether it is prose or poetry. This paper examines triad in epitaph lyrics of ancient Turks, identifies similarities and signs of continuity with the modern Tuvinian triad poetry "ozhuk dazhy" - "stones hearth", which, in our opinion, may be the basis in deciding to the poetic texts of ancient Turkic poetry. Consider the poetic features of ancient Turkic texts, comparing them with the Tuvan poetic material. The distinctive features of ancient Turkic from prose texts is not only poetic form (split into lines), but also stylistic and syntactic features inherent poetic work. Unlike modern Tuvan poetry, the ancient Turkic epitaphs (as in the inscriptions in honor of Cultegin, Tonyukuk, guesswork book, etc.) is not observed syllabic isosyllabism. In the definition versification of old Turkic poetry texts scholars have different opinions: A.M. Xherbak relates to the syllabic system, ${ }^{8}$ F.E. Korsch - to syllabic-tonic, ${ }^{9}$ I.V. Stebleva - to the tonic-temporal system. ${ }^{10}$ In our view, ancient Turkic inscriptions are free verse consisting of unequal poetic verse lines based depending on artistic intonation, like intonation and phrasal structure poems, are dismetric free verse.

I.V. Stebleva are quite right in asserting that rhyme in ancient poetry not, that the «ancient Turkic verse was alliterative tipe... alliteration at the beginning of verse performed rhythmic (recorded meter) and composite (strophic) function. ${ }^{10}$ Naturally, being the first of the monuments of ancient Turkic writing, these poetry do not have to rhyme, as such, in the modern sense. In our opinion, it is necessary to consider features of alliteration and rhyme in Turkic poetry, and in these texts one can find the beginnings of rhyme. In Tuvan poetry inherent alliterative rhyme, i.e. «initial rhyme». It should also be noted that for the Turkic poetic tradition of characteristic genetic language genetic tendency to parallelism. Besides the researches V.M. Zhirmunsky, A.N. Veselovskyi and other a rhythmicsyntactic parallelism interesting idea well as N.S. Trubetskoy about concurrency in Turkic poetry: “... most of parallelism gravitate tend either towards full semantic tautology or towards exclusively syntactic analogies, and more complex figurative comparisons are relatively rare". ${ }^{11}$ (emphasis added.- L.M.). These qualities of Turkic verse, in our opinion, are typical for the ancient Turkic poetry that dictate the specifics of the ancient Turkic verse - the finite rhyme, mostly in the form of tautological. Characteristic Tuvan poetry (poetry and of other Turkic- Mongol peoples) initial rhyme in them is rare. The main typological commonality with contemporary Tuvan poetry lies in the fact that they felt the inner rhythm of the verse, parallelism and tautological rhyme.

«I was a people constituting a tribal Union,

now, where is my tribal Union?

Based on these examples, we can say that for the ancient Turkic verse characteristic syntactic analogy, mainly as a kind semantic tautology, ie observed the beginnings of rhyme. The phenomenon of isosyllabism can be found: in the "Small inscription in honor of $\mathrm{Cul}$ tegin " - verses 1, 6, 7, 9, in "Big inscription in honor of Cul tegin " verses $2,8,9,13,15,16,23,24,27,29$, in "The Inscription in honor of Tonyukuk " - verses 14, 54, etc., characteristic in syllabic system of versification, which is characteristic of poetry Turko-Mongol peoples of Southern Siberia (Tuva, Altai, Buryatia, Shor, Khakassia, Yakutia). Abound in the examples metaphors, similes, and phraseological units, proverbs. Note that in these ancient texts sound organization (rhythmic repetition, assonance, dissonance, etc.) close to Tuvan modern poetry. In the following Yenisey inscriptions (inscriptions monuments of the Uyuc-Turan, Elegest, Baryk and others) can also be seen poetic qualities:

E -7

(3) deerde hunge, cherde uluzumga pökpedim.

(I didn't enjoy the sun in the sky, their loved ones on earth)

E-3

Aldyn ok havyn belimge bagladym. Deer uktug el-churtumga pökpedim.

(Golden quiver belt I wear.

I did not enjoy native land of heavenly origin)

E -45

(10) Chavysty KYmyl men bedik kyldym, silerge pökpedim.

(I Kumul, made low to high, I did not enjoy you)

M - 72

Kök tengride boltum...

(I found oneself on the blue sky...)

It should be noted that the artistic value of the Yenisei monuments are not fully appreciated. For example, without penetration into the emotional world of the ancient Turkic poetry is difficult, sometimes impossible, to catch all the tragedy and poetic words «(a)d(i)r(i)lt(i) m» (tuv. "adyryldym") of the Yenisei epitaphs that translated into Russian speaking little phrase «I separated», whereas in the context of the inscriptions, in addition to the bitterness of parting and farewell, audibly plaintive sigh and even sob. This word in Tuvan language sounds just and carries depending on the context the same meaning. Should also be noted that the word «(a)d(i)r(i)lt(i)m» is used in the texts as a metaphor - the presence in the ancient Turkic words «ölüm» death, «ölur» to die, «кet» to leave, disappear, to die. The emotional tone, emotional coloring, stylistic eagle words «(a)d(i)r(i) lt(i)m», in the words U.N. Tynyanov, «as a very important factor in the deployment of lyrical plot, the tone that word defines the essence of the poem». ${ }^{12}$ Metaphorical use of words as «kunç(u)y(i)m» my princess, «bökm(e)d(1)m» not enjoy, etc. A characteristic feature of the style of ancient epitaphs is a lament for the heavenly bodies, which will forever all is extinguished for heroes inscriptions:

«Blue teride kyn, ai azyidym»

(The sun and the moon in the blue sky I did not feel).

(trans. S.G. Klyashtorny and I.U. Sambuu). ${ }^{13}$

As in ancient inscriptions, in contemporary Tuvan poetry large semantic role played by images of light. For example, in the poems of the C. Purbu, C. Codagy, R. Ludup the image of the mother is compared with the Sun and the Moon (also with Buddhist deities):

Hunum, Aiym, Sagaan dariygi, Nogaan dariygi,

Hurgeldey huren chechee - kuzhur Avai!

Chymysh-bachym nyncha nazin durguzunda

Chyryk cherge chunu cherle korbedin deer... 
My sun, the moon, my White Tara, Green Tara,

Flower huregeldey brown - my dear mother!

What only you did not see in white light

For his age, filled with labor and care...

\section{(K. Kudazhy)}

You can also find a lot of poems, similar in style and rhythm, images and motifs coming from the secret depths of the heart, recreating crying, miserable sob associated with loss, separation from a loved one. For example:

Ori kustun hola saryg buruleri

Oruk-holun chulazy boop chyryp turlar.

Oran tandyn, avaiym see, soolgu belee.

Late autumn copper-yellow leaves

As Lantern illuminate your way.

This is the last you the gift of thy land, Mom.

$$
\text { (R. Ludup) }
$$

On the basis of editions and translations from the ancient language of the monuments Orkhon-Yenisei, submitted in works V.V. Radloff, S.E. Malov, I. A. Batmanov, A.C. Kunaa, Z.B. Aragachi (Chadamba), D.A. Mongouch and other identified a three-line poetic form. Verse form of inscriptions of these monuments was determined visually by scientists without poetic reconstruction. Of course, taken into account the fact that the inscriptions carved on stones. In Tuvan poetry the emergence of new genre triad in the late XX century. Inscriptions of the ancient Turks are studied by us as one of the possible origins of the genre ozhuk dazhy. Yenisei ancient Turkic inscriptions on the steles, named S.E. Malov «graveyard poetry» ${ }^{14}$ are small text, describing the glory and valour, life values of ancient warriors and expressing regret and bitterness of parting with life. Data epitaphs contain mostly appeal from the first person on behalf of the deceased noble, gallant hero. He probably left memory about the character closest to him, man, who knew his biography, important dates of his life, heroic deeds, and family.

Data epitaphs written mostly in one art form that indicates the existence of a common old Turkic literary tradition marking the grave of the illustrious commanders, heroes of poetic texts. Perhaps there were special «poets», which created the texts of epitaphs, covering the life of worthy people of this historical era, «poets», feeling the deep suffering of man go away into another world:

Ciz okunch eb bokmedim.

Tokuz yashda toglyk kanka tapdym erdim.

Bilmedim bunym... On ermish.

By you and sad house I didn't enjoy.

At nine I began to serve Toglyk Khan.

I did not know their sorrows...was Ten. ${ }^{15}$

(transl. Calamba Z.B.)

Feature style and expression, the poetry of these lines, in our opinion, is obvious. Despite its brevity, Yenisey inscriptions are mainly identical texts: i. Specifies the name of the hero, his formation (not all epitaphs), the title, rank and age;

ii. Marked heroic acts;

iii. Lyrical regret parting with this world, with family, loved ones and property.

Further focuses on the poetic features of ancient Turkic epitaphs. Here are some examples illustrating the proximity of the Yenisei epitaphs with modern form ozhuk dazhy.

The ancient tercet:

Kanymka, Elimke bekmedim

Kuyda kunchuyumka adyryldym

Kansyz caldym

I didn't enjoy my Khan, my State

I separated from my princess in the tower

I left without a father

(Translated Batmanov I.A). ${ }^{16}$

Ozhuk dazhy:

Ezhik chocta shoochanyn heree bar be?

Eshkiishtin-daa kheme chocta heree bar be?

Etken sostun bodal chocta heree bar be?

(E. Mizhit)

Do I need a lock, if there is no door?

Do I need oars, if there is no boat?

Do I need words, if the is no thought?

In these three verses triplets - as the stones of hearth - each is separate, i.e. contains a certain thought, and at the same time together constitute a unity, i.e. subordinate to the main poetic thought. Consequently, the three verses linked subordination of the common goal of expression. This triad forms a certain structure, where a parallel description of the phenomena of nature deepens the drama of the characters' feelings. Here also there is an analogy in stylistic, structural elements. Similarly, in the above ozhuk dazhy and ancient Turkic tercet, despite the dominance of free verse, there are the following compositional characteristics of the rhythmic organization (Of course, in ancient texts organization at an early stage of development).

I. syntactic parallelism - characteristic style;

II. anaphoric alliteration (initial rhyme);

III. rhyming grammatical type (final rhyme, in other epitaphs meet and assonance and rhyme-echo);

IV. pass-through alliteration (recording: alliterative sounds $-\mathrm{k}, \mathrm{m}$ ).

Comparison of ancient Turkic treastise Tuvan shows their identity in compositional aspect:

Comparison of ancient Turkic triplets and Tuvan triads shows their identity in compositional aspect: 


\author{
II monument Ikhe - Askhete \\ Uze tengri erklig $\mathrm{m}$... \\ Adrylmys olygime yglayu bertim \\ Chn... er bedizmish. \\ At the top strong sky \\ mourn the deceased... \\ ... the hero builded (monument). \\ (trans. V.V. Radloff) \\ Ozhuk dazhy: \\ Buzure, Idegel, Ynakshyl - \\ BYzyreldig Ush ydyk tandym. \\ Chazhyym chazhyp chalbardym.
}

(A. Darzhay)

Faith, Hope, Love -

Here are three of my Holy mountains.

Worship, sprinkling holy milk.

Analyze the composition of the inner triplets. The first line is the exposure, which gives introduction to the topic. The second line - revealed a poetic image of the poem. In the final line turns the poet's attitude to developing subject. Thus, three lines form a single dialectically interrelated (start - development - end) and harmonically balanced whole. In the poetics of these triplets observed the principle of deepening thoughts, culminating in a clear conclusion. So, in the process of analyzing a small triplets, we found that ozhuk dazhy and Yenisei triplets have some common features in the rhythmic organization, structure and composition. Naturally, we should not forget that ancient Turkic epitaphs are easier organization than ozhuk dazhy. ${ }^{17}$ Monuments Orkhon-Yenisey script with three-line inscriptions were recorded in Tuva, Mongolia, Kyrgyzstan and Khakassia. To date, revealed more than 20 monuments epitaph lyrics, decorated in the form of triplets. Also determined that out of 60 considered by us (published) monuments inscriptions 3 lines a lot more than 2, 4, 5 lines. This fact suggests that the miniature form, in particular, tercet existed in written culture of the ancient Turks and came to us in the form of eternity frozen in texts. They continued to live orally in the form of weeping, lamentations, blessings, which probably constituted an indivisible whole.

The above suggests that the ancient Turkic transtissue miniatures can be considered as one link in the evolution transtechnik forms, pronounced in contemporary Tuvan poetry in the form of the genre ozhuk dazhy, because, as noted by I.V. Stebleba, «achievements of the ancient culture of the people do not disappear completely, but in some form, manifested in the cultures of later epochs».. ${ }^{18,19}$ In our view, the existence of a Tuvan literature poetic form tercet ozhuk dazhy, which is artistic and aesthetic, stylistic characteristics similar to the ancient Turkic triplets, recorded mostly in the basin of the Yenisei River, confirms the continuity of traditions of ancient and modern literature. Epitaph poems of ancient Turks stands at the beginning of the evolution of the tercet genre system Tuvan poetry.

Consideration of the works of contemporary Tuvan literature in the context of the written heritage of the ancient Turks also confirms the idea of continuity of the traditions of artistic literature. Research and translation into modern Turkic languages, analysis of the poetics and style monuments Orkhon-Yenisey script requires further in-depth study for the preservation and transmission to future generations of the ancient Turkic artistic culture - one of the most ancient and with a deep and strong root system of world cultures.

\section{Acknowledgment}

None.

\section{Conflicts of interest}

The author declares that there is no conflict of interest.

\section{References}

1. Kultegin. Orkhon-Yenisey bizhiinin turaskaaldary (Monuments of the Orkhon-Yenisei script. Compiler of the collection - Aranchin YL Kyzyl. 1993.

2. Baimov RN. Great faces and literary monuments of the East. Ufa: Guillem. 2005.

3. Zhirmunski VM. Orkhon inscriptions - poetry or prose? The peoples of Asia and Africa. 1968;2.

4. Korsch FE. Ancient folk verse of Turkish tribes. ZVORAO. 1909; IX(IIIII):139-40;

5. Bernshtam AA. Socio-economic structure of the Orkhon-Yenisei Turks VI-VIII centuries. Moscow-Leningrad. 1946;37-38.

6. A. Bombachi. Turkic literature: Introduction to the history and style. In: Gaben AF. Ancient Literature: Foreign turcology. Science. 1986;191-293:294-343.

7. Zhirmunski VM. Some problems in the theory of Turkish folk verse. Türkological Collection. 1970;56-68.

8. Xherbak AM. Yenisei runic inscriptions. On the history of the discovery and study. Türkological Collection. 1970;119-122.

9. Its the same. Value for alliteration and rhyme in Turkish prosody. NAA. 1961.

10. Stebleva IV. Poetry ancient Turks VI-VIII centuries. Moscow: Nauka. 1965.

11. Korsch FE. Ancient folk verse Turkish tribes. ZVORAO. 1909. IX.

12. Stebleva IV. Development of Turkic poetic forms XI century. Moscow: Nauk. 1971.

13. Troubetzkoy NS. About Turanian element in Russian culture. History Culture Language. Moscow: Publishing House Group Progress. 1995.

14. Tynyanov YA. The problem of poetic language. Moscow: Sov writer. 1965.

15. Klyashtorny SG, Sambuu IU. New runic inscription in Ulug-Khem district. Proceedings of Tuva Research Institute of Language, Literature and History. 1971;15.

16. Malov SE. Yenisei writing Turks. Moscow-Leningrad. 1962.

17. Batmanov IA, Kunaa AC. Monuments of Ancient writing Tuva. 1963.

18. Mizhit LS. Ancient Turkic monuments as a historical and cultural source of Tuvan literature. The history of Tuvan literature. Vol I. Origins. Literature of The Tuvan People's Republic (1921-1944)]. Novosibirsk: Publishing house SB RAS. 2013.

19. Poetry ancient Turks VI-XII centuries. Translations A Prelovskiy Verse rekonstr. scientific translation introduction article IV comments IV Stebleva. 1993. 